\title{
Impact of gamma irradiation pretreatment on biochemical and molecular responses of potato growing under salt stress
}

\author{
Elhamahmy Ali Mohamed', Elsadany Osama', Eid Manal ', Abdelazeem Samah', Gerish Salah', \\ Kalaji M. Hazem ${ }^{2^{*}}$, Wróbel Jacek ${ }^{3}$ and Elsheery Nabil ${ }^{4^{*}}$
}

\begin{abstract}
Background: Previous literatures revealed that gamma rays have an increasing effect on salt tolerance in different plants. In vitro experiment was conducted to study the effect of gamma rays (20 Gray) on salt tolerance of four potato cultivars (Lady Rosetta, Diamante, Gold, and Santana).

Results: Gamma-treated Santana plantlets were more tolerant to salinity as compared to other cultivars. It showed a significant increment of fresh weight (250\% over the untreated). Gamma-treated plantlets of Lady Rosetta, Diamante, and Gold showed higher activity of peroxidase (POD) and polyphenol oxidase (PPO). Isoenzymes analysis showed an absence of POD 3, 4, and 5 in Gold plantlets. The dye of most PODs and PPOs bands were denser (more active) in gamma-treated plantlets of Santana as compared to other cultivars. Both gamma-treated and untreated plantlets showed the absence of PPO1 in Lady Rosetta and Diamante, and PPO 3, 4, and 5 in Gold plantlets. Genetic marker analysis using ISSR with six different primers showed obvious unique negative and positive bands with different base pairs in mutant plantlets as compared to the control, according to primer sequence and potato genotype. The 14A primer was an efficient genetic marker between mutated and unmutated potato genotypes. Santana had a unique fingerprint in the 1430-pb site, which can be a selectable marker for the cultivar. An increment in genetic distance between Gold cultivar and others proved that the mutation was induced because of gamma rays.
\end{abstract}

Conclusion: We assume that irradiation of potato callus by 20-Gy gamma rays is an effective process for inducing salt resistance. However, this finding should be verified under field conditions.

Keywords: Solanum tuberosum L., Callus, ISSR, Peroxidase, Polyphenol oxidase, Isoenzymes

\section{Background}

Potato (Solanum tuberosum L.), a member of Solanaceae family, has a high economic value in domestic and global markets. Potato tubers are known for their high nutritional value $(20-30 \%$ starch, $2 \%$ protein, vitamins B1, B2,

\footnotetext{
*Correspondence: hazem@kalaji.pl; nshery@yahoo.com

${ }^{2}$ Department of Plant Physiology, Institute of Biology, Faculty of Agriculture and Biology, Warsaw University of Life Sciences, 02-776 Warsaw, Poland

${ }^{4}$ Agriculture Botany Department, Faculty of Agriculture, Tanta University, Tanta, Egypt

Full list of author information is available at the end of the article
}

C, minerals, etc.). Potato cultivars such as Lady Rosetta are used for cooking and in chips industry. Cultivars such as Diamante and Santana with superficial eyes-tubers, creamy pulp and more than $20 \%$ of dry matter are used as half-fried [1].

Potato is a moderately salt-tolerant vegetable crop $(1.7 \mathrm{dS} / \mathrm{m}=1088 \mathrm{ppm})$. Plant growth and productivity are affected by salinity [2-5]. Salt stress negatively affects tuber sprouting, adventitious root development and biomass production, which significantly reduce yield [6]. Salt-stressed plants induce ionic and osmotic stress signals to re-establish cellular homeostasis and 
detoxification signals to repair stress damages coordinate cell division [7].

Commercial cultivars of potato are tetraploid $(2 n=4 x=$ 48) and extremely heterozygous, with simplex inheritance (Aaaa) for different characteristics. Genetic manipulation in potato could be easily conducted through tissue culture technique and conventional breeding methods [8].

Previous reports revealed that radiation was an effective method to increase tolerance on plants against factors such as salt and drought stress [9-12]. Gamma radiation is the most preferred physical mutagen by plant breeders. The impact of radiation is mainly related to the species, cultivar, and plant age, physiology, morphology and genetic organization. Ionizing radiation causes structural and functional changes in DNA molecule, which have role at cellular and systemic levels. The nature of DNA modifications includes base alteration, substitution, and deletion, in addition to chromosomal aberration, as reported by [13].Afrasiab and Iqbal [14] selected six gamma mutant lines of potato in terms of average shoot height, number of shoot/plant, number of nodes/ shoot, average tuber number, size and weight, and number of eyes/tuber. Cheng et al. [15] found that radiation with 20 Gy in Shepody potato improved tuber formation. The average number and diameter of Minitubers (V1) were significantly increased over the control by $71 \%$ and $34 \%$, respectively. The higher the radiation dose of 40 and $50 \mathrm{~Gy}$, the lower the emergence percentage, plant height and root length of mini-tuber potato plants with about $67 \%$ and $31 \%$ for each dose, respectively. Yaycili and Alikamanoğlu [16] obtained salt-tolerant mutants of Marfona potato using gamma irradiation (20 or 30 Gy) and regenerated them on selection medium containing $100 \mathrm{mM} \mathrm{NaCl}$. A polymorphism rate of $89.66 \%$ was calculated to the selected primers using Inter simple sequences repeat (ISSR) technique, and the mutants were $27.5 \%$ genetically different from the control plants. Molecular markers such as enzymes and protein are considered one of the effective indicators to differentiate between varieties, DNA identification and genetic compatibility, as well as the detection of genetic variability of plants susceptible to mutagenesis by comparing the results of DNA analysis with the origins. The reliability of the used primers is considered as a function of environmental stresses [17]. Inter Simple Sequences Repeat (ISSR) markers provide greater opportunities in determining the exact relationship between a specific DNA sequence and the examined trait, and also in determining a plant's identity using particular genes. ISSR is popular DNA fingerprinting method, because it is inexpensive, highly polymorphic, quick, and easy to perform [18]. The primers are designed using microsatellite sequences to amplify the genomic regions flanked by microsatellite repeats. It is possible to amplify multiple fragments using one primer of ISSR analysis. The information obtained from ISSR analysis is more reliable than RAPD to supply supplementary data of genetic variations of the mutants from non-overlapping genome regions [18]. Yaycllı and Alikamanoğlu [16] show $89.66 \%$ polymorphism rate with six primers among mutant potato plants, which were improved as salt-tolerant using gamma radiation. AL-Hussaini et al. [19] studied the Differential Display Reverse Transcriptase (DDRT) as a genetic marker for salt tolerance in mutant clones of potato calli exposed to 8,10 and $12 \mathrm{dSm}^{-1}$ and their parental cultivars (Riviera and Burren) using 10 randomized primers. They stated that RNA concentration of 103.0 and $226.0 \mathrm{ng} \mathrm{mmol}^{-1}$ showed a purity of 1.86 and 2.01, respectively. DDRT with seven primers succeeded to amplify DNA fragments involved in salt tolerance. Cluster analysis separated genotypes in groups with a range of genetic variability among them.

The aim of this research was to study the differential ISSR amplified fragments over four potato cultivars (Lady Rosetta, Diamante, Gold and Santana) and to examine the ability of gamma rays for inducing salt resistant in potato cultivars, then confirm these results using molecular characteristics under field conditions compared with non-irradiated plantlets.

\section{Methods}

In vitro propagation of potato cultivars and the application of gamma rays

Plantlets of Lady Rosetta, Diamante, Gold and Santana cultivars were kept at $4{ }^{\circ} \mathrm{C}$, and then stored in dark at $25^{\circ} \mathrm{C}$ for 2 weeks until developing $5-6 \mathrm{~cm}$-height sprouts [20]. Samples of $1-2 \mathrm{~mm}$-length sprouts were collected and sterilized with $1 \%$ sodium hypochlorite for $3 \mathrm{~min}$., and dipped in absolute ethanol, then washed in sterilized water for 5 minutes before cultivating on half-strength Murashige and Skoog's medium (MS) [21]. Shoot tips (10 $\mathrm{mm}$ ) were cultivated on callus production medium (containing $1 \mathrm{mg} / \mathrm{L}$ of NAA (naphthalene acetic acid) and 0.5 $\mathrm{mg} / \mathrm{L}$ of BAP (benzyl amino purine). All cultures were stored in a culture room at light/dark photoperiod (16/8 h) and $25^{\circ} \mathrm{C}$. Two weeks later, calluses were initiated, and then 4 segments of callus $\left(\approx 1 \mathrm{~cm}^{2}\right)$ from each container were sub-cultured on the same medium at an interval of 2 weeks. Twenty containers having four segments of callus were then treated with 20 Gray (Gy) gamma rays $(\approx 0.653$ $\mathrm{rad} / \mathrm{Sec}$ ) for $30 \mathrm{~min}$ (137Cs-Gamma Cell-40, Canada) at the Egyptian Atomic Energy Authority, Egypt. Potato callus was irradiated by rotating $360^{\circ}$ in a cylindrical radiation field. Radiation was repeated twice at an interval of 7 days. All experiments were represented by 4 replicates in a completely randomized design [22]. Differentiated 
calluses on half-MS medium without growth hormones produced complete plantlets. Uniform plantlets $(3 \mathrm{~cm}$ height) were examined for salt tolerance by adding 2720 ppm of $\mathrm{NaCl}\left(4 \mathrm{dSm}^{-1}\right)$ to MS media. After 1 month, the fresh weight (FW) of gamma-treated and control plantlets was measured (g). The biochemical and molecular analysis of potato plantlets were also carried out:

\section{Activity of peroxidase (POD) and polyphenol oxidase (PPO) Enzyme extraction}

$200 \mathrm{mg}$ of fresh plantlets were homogenized with $10 \mathrm{ml}$ of $0.1 \mathrm{M}$ phosphate buffer ( $\mathrm{pH} 6.8)$, and then centrifuged $\left(20000 \mathrm{rpm}\right.$ ) at $20{ }^{\circ} \mathrm{C}$ for $20 \mathrm{~min}$. The clear supernatant was collected for the determination of enzyme activities [23].

\section{Activity of POD (EC 1.11.1.7)}

The activity of POD was assayed using a solution containing $5.8 \mathrm{ml}$ of $50 \mathrm{mM}$ phosphate buffer ( $\mathrm{pH} 7.0), 0.2 \mathrm{ml}$ of the enzyme extract, and $2 \mathrm{ml}$ of $20 \mathrm{mM} \mathrm{H}_{2} \mathrm{O}_{2}$ after the addition of $2 \mathrm{ml}$ of $20 \mathrm{mM}$ pyrogallol. The rate of increase in absorbance as pyrogallol was determined spectrophotometrically using UV-spectrophotometer for $60 \mathrm{sec}-$ ond at $470 \mathrm{~nm}$ and $25{ }^{\circ} \mathrm{C}$. One unit of enzyme activity was defined as the amount of the enzyme that catalyzed the conversion of one micromole of $\mathrm{H}_{2} \mathrm{O}_{2}$ per minute at $25{ }^{\circ} \mathrm{C}$. The blank sample was made using buffer instead of enzyme extract according to [24].

\section{Activity of PPO (EC 1.10.3.1)}

The activity of PPO was determined using $125 \mu \mathrm{mol}$ of phosphate buffer (pH 6.8), $100 \mu \mathrm{mol}$ pyrogallol, and $2 \mathrm{ml}$ of enzyme extract. After the incubation period of $5 \mathrm{~min}$ at $25{ }^{\circ} \mathrm{C}$, the reaction was ceased with the addition of $5 \%$ $\mathrm{H}_{2} \mathrm{SO}_{4}(1 \mathrm{ml})$. The blank sample was made using a very well boiled enzyme extract, and the developed color was read at $430 \mathrm{~nm}$. Enzyme activity was expressed as the changes in the optical density/g fresh weight/h [25].

\section{Isoenzymes of POD and PPO}

Polyacrylamide gel electrophoresis (PAGE) was conducted to identify isoenzyme variations, among the studied gamma-treated plantlets and the control, using peroxidase (PODs) and polyphenol oxidase (PPO) according to [26]. Isoenzymes were extracted by homogenizing $0.5 \mathrm{~g}$ fresh samples in $1 \mathrm{ml}$ extraction buffer $(10 \%$ glycerol), and the extract was centrifuged at $10000 \mathrm{rpm}$ for 5 minutes. The supernatant was used for electrophoretic analysis. A sample of $40 \mu \mathrm{l}$ extract was mixed with $20 \mu \mathrm{l}$ sucrose and $10 \mu$ bromophenol blue, and then a volume of $50 \mu \mathrm{l}$ of this mixture was applied to each well. Gel run was performed at $150 \mathrm{~V}$ until the bromophenol blue dye has reached the separating gel, and then voltage was increased to $200 \mathrm{~V}$. Electrophoresis apparatus was placed inside a refrigerator during the run.

\section{$P O D$ staining and detection}

After electrophoresis, the gel was stained with benzidine di- $\mathrm{HCl}(0.125 \mathrm{gm})$, glacial acetic acid $(2 \mathrm{ml})$ and the mixture was toped up to $50 \mathrm{ml}$ with distilled water. Gel was placed into this solution, and 5 drops of hydrogen peroxide was added. The gel was incubated at room temperature until bands appear as described by [27].

\section{PPO staining and detection}

The gel was stained with $0.1 \mathrm{M}$ of phosphate buffer $(\mathrm{pH}$ 6.5), $100 \mathrm{mg}$ of sulfanilic acid, $200 \mathrm{mg}$ catechol in $2 \mathrm{ml}$ acetone. The gel was then placed into this solution and incubated at $30^{\circ} \mathrm{C}$ for $30 \mathrm{~min}$ until the bands appeared, and then gels were scanned and analyzed using Gel Doc Vilber Lourmat system.

\section{ISSR analysis \\ Genomic DNA extraction}

Genomic DNA was extracted using $500 \mathrm{mg}$ of plantlets with $400 \mu \mathrm{l}$ extraction buffer containing $200 \mathrm{mM}$ Tris$\mathrm{HCl}$ (pH 7.5), $250 \mathrm{mM} \mathrm{NaCl}, 25 \mathrm{mM}$ EDTA (pH 8.0) and SDS $(0.5 \%)$. This mixture was vortexed in Eppendorf tubes for $20 \mathrm{~s}$, and warmed in water bath at $65^{\circ} \mathrm{C}$ for 15 min, and $200 \mu \mathrm{l}$ sodium acetate $(3 \mathrm{M})$ was added to the solution and centrifuged at $13.000 \mathrm{rpm}$ for $10 \mathrm{~min}$. The supernatant $(500 \mu \mathrm{l})$ was transferred to new Eppendorf with $500 \mu \mathrm{l}$ cold isopropanol, and shaken for $5 \mathrm{~min}$. then centrifuged at $13.000 \mathrm{rpm}$ for $10 \mathrm{~min}$. The residual was washed with $200 \mu \mathrm{l}$ cold ethyl alcohol (70\%) then centrifuged at $13.000 \mathrm{rpm}$ for $5 \mathrm{~min}$. This step was repeated twice, and then $50 \mu \mathrm{d}_{2} \mathrm{O}$ was added to the dry residual and stored at $-20^{\circ} \mathrm{C}$ overnight, followed by the addition of $1 \mu \mathrm{l}$ RNAase $\left(10 \mathrm{mg} / 1 \mathrm{ml} \mathrm{H}_{2} \mathrm{O}\right)$ and incubation at $37{ }^{\circ} \mathrm{C}$

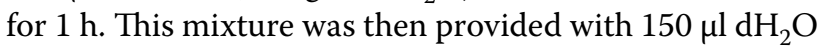
and $200 \mu \mathrm{l}$ phenol and shaken well for $2 \mathrm{~min}$., and then centrifuged at 13,000 rpm for $10 \mathrm{~min}$. The supernatant was mixed with $100 \mu \mathrm{l}$ phenol, $100 \mu \mathrm{l}$ chloroform and shaken for $2 \mathrm{~min}$, followed by centrifugation at 13.000 $\mathrm{rpm}$ for $10 \mathrm{~min}$. Dried residual was mixed with $50 \mu \mathrm{l}$ $\mathrm{dH}_{2} \mathrm{O}$ and stored at $-20^{\circ} \mathrm{C}$ [28]. The primers names and their nucleotide sequences used for ISSR procedure are listed in Table 1.

\section{Polymerase chain reaction (PCR)}

The amplification of DNA was performed in an automated thermal cycle (model Techno 512) programmed for one cycle at $94{ }^{\circ} \mathrm{C}$ for $4 \mathrm{~min}$, followed by 45 cycles of $1 \mathrm{~min}$ at $94{ }^{\circ} \mathrm{C}, 1 \mathrm{~min}$ at $57{ }^{\circ} \mathrm{C}$, and $2 \mathrm{~min}$ at $72{ }^{\circ} \mathrm{C}$. The reaction was finally stored at $72{ }^{\circ} \mathrm{C}$ for $10 \mathrm{~min}$. PCR was performed in $30 \mu \mathrm{l}$-volume tubes that contained $3 \mu \mathrm{l}$ 
Table 1 List of the primer names and their nucleotide sequences used for ISSR procedure

\begin{tabular}{llllll}
\hline No. & Name & Sequence & No. & Name & Sequence \\
\hline 1 & 14A & 5 CTC TCT CTC TCT CTC TTG 3' & 4 & HB-11 & $5^{\prime}$ GTG TGT GTG TGT TGT CC 3' \\
2 & 44B & 5' CTC TCT CTC TCT CTC TGC 3' & 5 & HB-13 & $5^{\prime}$ GAG GAG GAG C 3' \\
3 & HB-9 & 5' CAC CAC CAC GC 3' & 6 & HB-15 & $5^{\prime}$ GTG GTG GTG GC 3' \\
\hline
\end{tabular}

Table 2 Fresh weight (g) of potato plantlets (30 days old) as affected by gamma rays after the application of $\mathrm{NaCl}\left(4 \mathrm{dSm}^{-1}\right)$

\begin{tabular}{llll}
\hline Cultivars & Control & $\begin{array}{l}\text { Gamma } \\
\text { irradiation }\end{array}$ & \% of control \\
\hline Lady Rosetta & $3.2 \mathrm{e}$ & $6.9 \mathrm{~b}$ & 115 \\
Diamante & $4.1 \mathrm{~d}$ & $8.5 \mathrm{a}$ & 107 \\
Gold & $2.6 \mathrm{f}$ & $5.6 \mathrm{c}$ & 115 \\
Santana & $1.6 \mathrm{~g}$ & $5.6 \mathrm{c}$ & 250 \\
\hline
\end{tabular}

Values followed by the same letter within a column are not significantly different at $P \leq 5 \%$ using Duncan's multiple range test (DMRT)

dNTPs (2.5 mM), $3 \mu \mathrm{l} \mathrm{MgCl} 2$ (25 mM), $3 \mu \mathrm{l}$ Buffer (10 x), $2 \mu \mathrm{l}$ primer $(10 \mathrm{pmol}), 0.2 \mu \mathrm{l}$ Taq DNA polymerase (5U/ $\mu \mathrm{l}), 2 \mu \mathrm{l}$ Template DNA (25 ng) and $16.8 \mu \mathrm{l} \mathrm{H}_{2} \mathrm{O}(\mathrm{dw})$, according to [29].

Agarose (1.5\%) was warmed with $100 \mathrm{ml}$ of TBE (Tris/ borate/EDTA) buffer, and then $5 \mu$ l ethidium bromide was added after the temperature became $55{ }^{\circ} \mathrm{C}$. Samples of DNA amplified product $(15 \mu \mathrm{l})$ was loaded in each well. DNA ladder (100 bp) mix was used as standard DNA with molecular weights of 3000, 1500, 1000, 900, $800,700,600,500,400,300,200$ and $100 \mathrm{bp}$. The run was performed for about $30 \mathrm{~min}$ at $80 \mathrm{~V}$ in mini submarine gel BioRad. The Cluster analyses were done using Gel works in ID advanced software UVP-England Program.
[30]. The polymorphism percentage was calculated, according to [31].

\section{Statistical analysis}

Data were statistically analyzed using the MSTAT-C statistical analysis package [32] and means were separated using LSD test at $P \leq 0.05$.

\section{Results}

\section{Effect of gamma rays on fresh weight}

Our results revealed that salt-stressed Diamante potato plantlets treated with gamma rays have the highest significant values of fresh weight $(8.5 \mathrm{~g})$ compared to the control (Table 2). Fresh weight of gamma-treated plantlets of Santana potato has increased by $250 \%$ over the control.

\section{Effect of gamma rays on antioxidant enzymes}

Both peroxidase (POD) and polyphenol oxidase (PPO) had increased in gamma-treated plantlets over the control of four potato cultivars (Fig. 1). The highest increment of POD and PPO activity was seen in gammatreated plantlets of Lady Rosetta, Diamante and Gold cvs.

\section{Effect of gamma irradiation on isoenzymes of POD}

Three isoenzymes of POD (3,4 and 5) were disappeared as a result of gamma rays application on salt-stressed Gold potato, as shown in Fig. 2 and Table 3. Density of
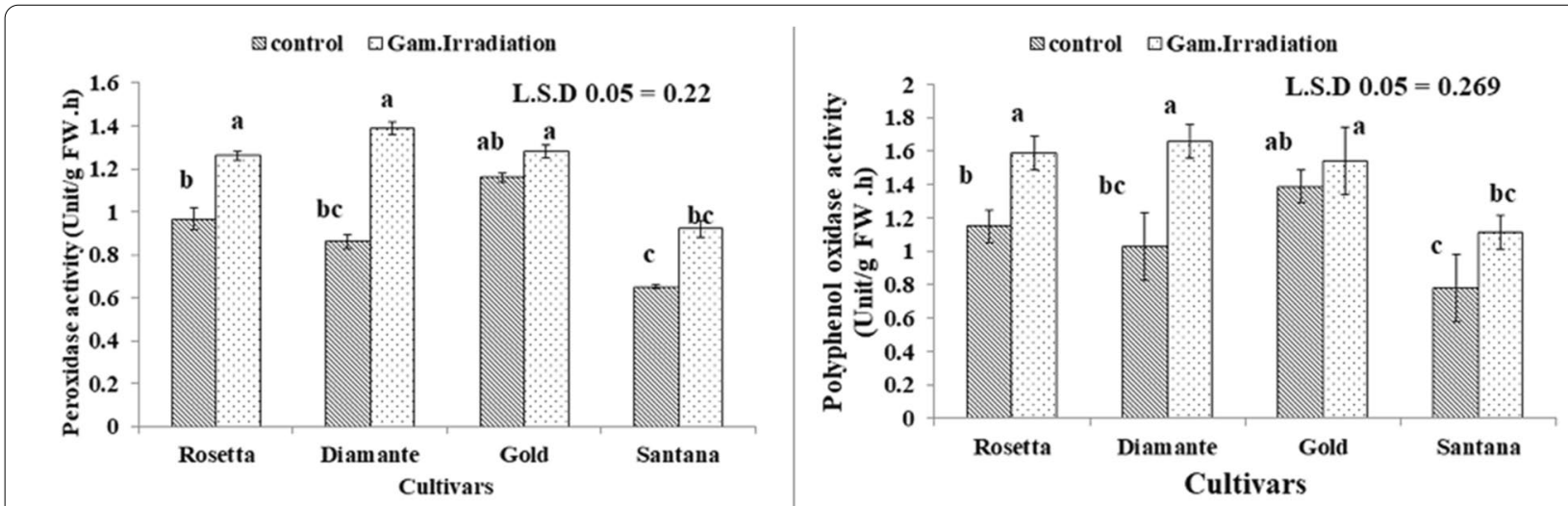

Fig. 1 Effect of gamma irradiation on peroxidase (POD) and polyphenol oxidase (PPO), in four potato cultivars after 30 days of $\mathrm{NaCl}(4 \mathrm{dS} / \mathrm{m})$ exposure. Values followed by the same letter within a column are not significantly different at the $5 \%$ level of probability according to Duncan's multiple range test 
isoenzymes bands has differed according to cultivar and gamma rays treatment. In this respect, density of all PODs isoenzymes bands was high in salt-tolerant Santana potato.

\section{Effect of gamma irradiation on isoenzymes of PPO}

Both gamma-treated and untreated plantlets of Gold and Santana cvs. had shown five isoenzymes of PPO compared to only four isoenzymes in Lady Rosetta and Diamante cvs. [-PPO 1] (Fig. 3 and Table 4). In addition, three bands of PPO 3, 4 and 5 were disappeared in Gold cv. because of gamma rays application. Gamma-treated Plantlets of Santana cv. showed high density of PPO1, 2 and 3, compared to all other cultivars.

\section{Molecular characteristics of six ISSR primers}

Six ISSR primers were amplified to detect the genetic changes among mutated and unmutated plants, and display the perceptive polymorphism concerning ISSR amplified fragments in four potato cultivars. As expected, the range of amplified sizes by each primer across different mutated and control plants was noteworthy [100 bp in 44B to1430 bp in HB15) (Table 5). However, the amplified DNA fragments had been categorized into

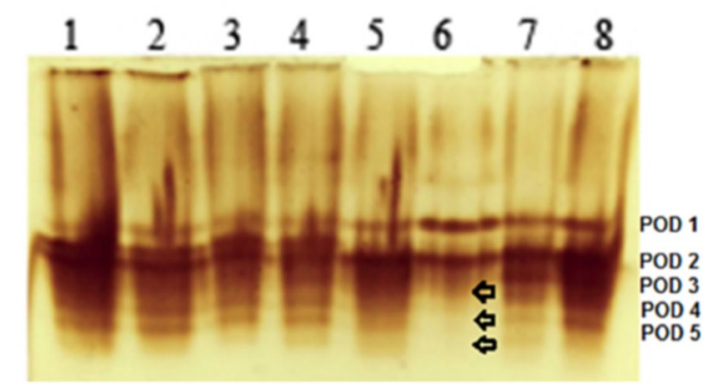

Fig. 2 Isoenzymes profile of peroxidases (PODs) as affected by gamma rays, in four potato cultivars after 30 days of $\mathrm{NaCl}(4 \mathrm{dS} / \mathrm{m})$ exposure. Lanes 1, 3, 5 and 7 untreated Lady Rosetta, Diamante, Gold and Santana; lanes 2, 4, 6 and 8 gamma-treated ones

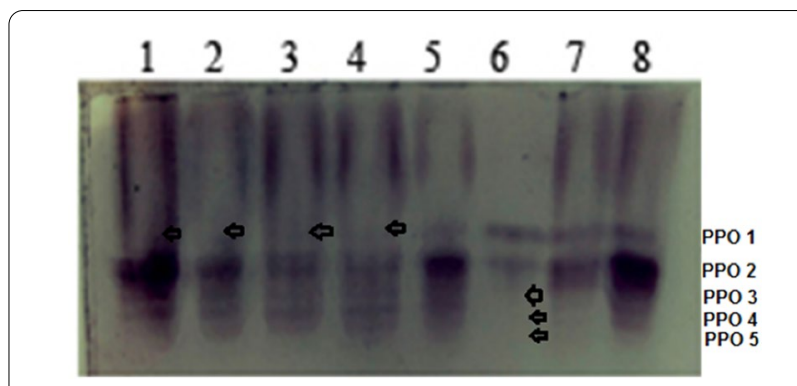

Fig. 3 Isoenzymes profile of polyphenol oxidase (PPO) as affected by gamma rays, in four potato cultivars after 30 days of $\mathrm{NaCl}(4 \mathrm{dS} / \mathrm{m})$ exposure. Lanes 1, 3, 5 and 7 untreated Lady Rosetta, Diamante, Gold and Santana; lanes 2, 4, 6 and 8 gamma-treated ones

polymorphic and monomorphic fragments. The total number of bands produced 34 bands with average of 5.7 bands per primer. The $\mathrm{Hb} 15$ primer produced the highest number of bands (8), while the HB13 primer produced the lowest number of bands (4). Moreover, Table 5 reveals that out of 34 bands scored, 22 bands were monomorphic identical for all mutated and control plants. The percentage of polymorphic bands recorded for each primer was not associated to the total number of bands. For example, the total number of bands scored for HB9 primer and $\mathrm{Hb} 15$ primer was high (7 and 8, respectively, with $29 \%$ and $50 \%$ of them being polymorphic). In contrast, $14 \mathrm{~A}$ primer produced 5 bands and $60 \%$ of them were polymorphic.

The genetic variations of the control plants for all four potato cultivars, and their mutated plants have been revealed by six ISSR markers (Fig. 4 and Table 6). Therefore, ISSR profile of mutated plants of Lady Rosetta lost two bands ( 30 bands) compared to the control plants (32 bands). On the other hand, the mutated plants gained several bands (29 bands and 30 bands) than losing bands, as in Gold and Santana cvs., respectively. Diamante cv. did not show any difference on the number of bands for both mutated and control plants (30 bands). Control plants of Santana cultivar showed negative unique

Table 3 Ideogram of POD isoenzymes as affected by gamma rays in four potatoes cultivars after the exposure to $4 \mathrm{dS} / \mathrm{m}$ of $\mathrm{NaCl}$

\begin{tabular}{|c|c|c|c|c|c|c|c|c|c|}
\hline \multirow{3}{*}{$\begin{array}{l}\text { Peroxidase } \\
\text { isoforms }\end{array}$} & \multirow{3}{*}{$\begin{array}{l}\text { Relative } \\
\text { mobility }\end{array}$} & \multicolumn{8}{|c|}{ Cultivars } \\
\hline & & \multicolumn{2}{|c|}{ Lady Rosetta } & \multicolumn{2}{|c|}{ Diamante } & \multicolumn{2}{|l|}{ Gold } & \multicolumn{2}{|c|}{ Santana } \\
\hline & & Con & Tre & Con & Tre & Con & Tre & Con & Tre \\
\hline POD 1 & 0.55 & $1^{+}$ & $1^{+}$ & $1^{+}$ & $1^{+}$ & $1^{+}$ & $1^{++}$ & $1^{+}$ & $1^{++}$ \\
\hline POD2 & 0.60 & $1^{++}$ & $1^{+}$ & $1^{+}$ & $1^{+}$ & $1^{+}$ & $1^{++}$ & $1^{++}$ & $1^{++}$ \\
\hline POD3 & 0.65 & $1^{++}$ & $1^{+}$ & $1^{+}$ & $1^{+}$ & $1^{++}$ & - & $1^{+}$ & $1^{++}$ \\
\hline POD4 & 0.70 & $1^{+}$ & $1^{+}$ & $1^{+}$ & $1^{+}$ & $1^{++}$ & - & $1^{+}$ & $1^{++}$ \\
\hline POD5 & 0.75 & $1^{+}$ & $1^{+}$ & $1^{+}$ & $1^{+}$ & $1^{-}$ & - & $1^{+}$ & $1^{++}$ \\
\hline
\end{tabular}

-low density, + moderate density, ++ high density, _ absent band 
Table 4 Ideogram of PPO isoenzymes as affected by gamma rays in four potatoes cultivars after the exposure to $4 \mathrm{~s} d S / m$ of $\mathrm{NaCl}$

\begin{tabular}{|c|c|c|c|c|c|c|c|c|c|}
\hline \multirow{3}{*}{$\begin{array}{l}\text { Polyphenol oxidase } \\
\text { isoforms }\end{array}$} & \multirow{3}{*}{$\begin{array}{l}\text { Relative } \\
\text { mobility }\end{array}$} & \multicolumn{8}{|c|}{ Cultivars } \\
\hline & & \multicolumn{2}{|c|}{ Lady Rosetta } & \multicolumn{2}{|c|}{ Diamante } & \multicolumn{2}{|c|}{ Gold } & \multicolumn{2}{|c|}{ Santana } \\
\hline & & Con & Tre & Con & Tre & Con & Tre & Con & Tre \\
\hline PPO 1 & 0.55 & - & - & - & - & $1^{+}$ & $1^{++}$ & $1^{+}$ & $1^{++}$ \\
\hline PPO 2 & 0.60 & $1^{++}$ & $1^{+}$ & $1^{+}$ & $1^{+}$ & $1^{++}$ & $1^{+}$ & $1^{+}$ & $1^{++}$ \\
\hline PPO 3 & 0.65 & $1^{++}$ & $1^{+}$ & $1^{+}$ & $1^{+}$ & $1^{++}$ & - & $1^{+}$ & $1^{++}$ \\
\hline PPO 4 & 0.70 & $1^{++}$ & $1^{+}$ & $1^{+}$ & $1^{+}$ & $1^{+}$ & - & $1^{-}$ & $1^{++}$ \\
\hline PPO 5 & 0.75 & $1^{+}$ & $1^{+}$ & $1^{+}$ & $1^{+}$ & $1^{+}$ & _ & $1^{-}$ & $1^{+}$ \\
\hline
\end{tabular}

- low density, + moderate density, + + high density, _ absent band

Table 5 Molecular characteristics of six ISSR primers used to analyze mutated and control plants of four potato cultivars

\begin{tabular}{|c|c|c|c|c|c|}
\hline Primers & Band size (bp) & Total bands & Poly-bands & Mono-bands & $\begin{array}{l}\text { Polymorphism } \\
\%\end{array}$ \\
\hline $14 \mathrm{~A}$ & $230-680$ & 5 & 3 & 2 & 60 \\
\hline $44 \mathrm{~B}$ & $100-415$ & 5 & 1 & 4 & 20 \\
\hline HB9 & $185-1360$ & 7 & 2 & 5 & 29 \\
\hline HB11 & $340-1080$ & 5 & 1 & 4 & 20 \\
\hline HB13 & $265-480$ & 4 & 1 & 3 & 25 \\
\hline HB15 & $430-1430$ & 8 & 4 & 4 & 50 \\
\hline Over total & & 34 & 12 & 22 & 34 \\
\hline
\end{tabular}

band with 570 bp corresponding to HB9 primer, while control plants of Gold cultivar revealed negative unique bands with 1080 bp using HB11 primer. Moreover, many constant bands (800 bp and 715 bp of both HB9 and HB15 primers, respectively) appeared in both control and mutated plants of Lady Rosetta and Diamante, but they disappeared in Santana and Gold cvs. They could be genetically related to genotypic of cultivar plants or to the germination and growth processes of the plants. Mutated plants of Diamante and Gold cvs. showed negative unique bands with $415 \mathrm{bp}$ and 965 bp corresponding to $44 \mathrm{~B}$ and $\mathrm{HB} 15$ primers, respectively. Meanwhile, a positive unique band with $820 \mathrm{bp}$ was found in mutated plants of Gold cultivar.

Genetic similarity was calculated for all four potato cultivars and found varied from 0.812 (Santana vs. Diamond) to 0.938 (Rosetta vs. Diamond). The high value of genetic similarity between Rosetta and Diamond could be a sign that a large part of the genome of both cultivars under study is identical.

A dendrogram based on UPGMA analysis with ISSR data (similarity matrix) is illustrated in Fig. 5. The four potato cultivars were divided into two main clusters. The first cluster has included Rosetta and Diamond cultivars that they were closed to each other, while the second cluster has included Gold and Santana cultivars. Genetic similarity was calculated for mutated plants of four potato cultivars and was varied from 0.788 (Gold vs. Diamante) to 0.875 (Rosetta vs. Diamante) and (Santana vs. Diamante).

A dendrogram based on UPGMA analysis with ISSR data (similarity matrix) is illustrated in Fig. 5. The mutated plants of four potato cultivars were divided into two main clusters. Mutated Gold cultivar separated from the other three cultivars. The second cluster was divided into two groups. Subgroup1 has included Santana and Diamante, while Rosetta was in subgroup 2. However, there were differences in genetic similarity of the control and mutated plants of the studied cultivars. For instance, Gold and Diamante were partly closed in the control plants, but they were far away from each other in the mutated plants (Fig. 6).

\section{Discussion}

Gamma treatment had more pronounced effect on the fresh weight of potato plantlets of all cultivars grown under salinity conditions (Table 1). Its effect was different from one potato genotype to another. Vigorous growth under stressful conditions is often required suitable physiological status related to enzymes and other molecules. Results confirmed the increment of the activity of both antioxidant enzymes; peroxidase (POD) and polyphenol oxidase (PPO) in gamma-treated plantlets in comparison to the untreated ones (Fig. 1). In the same 


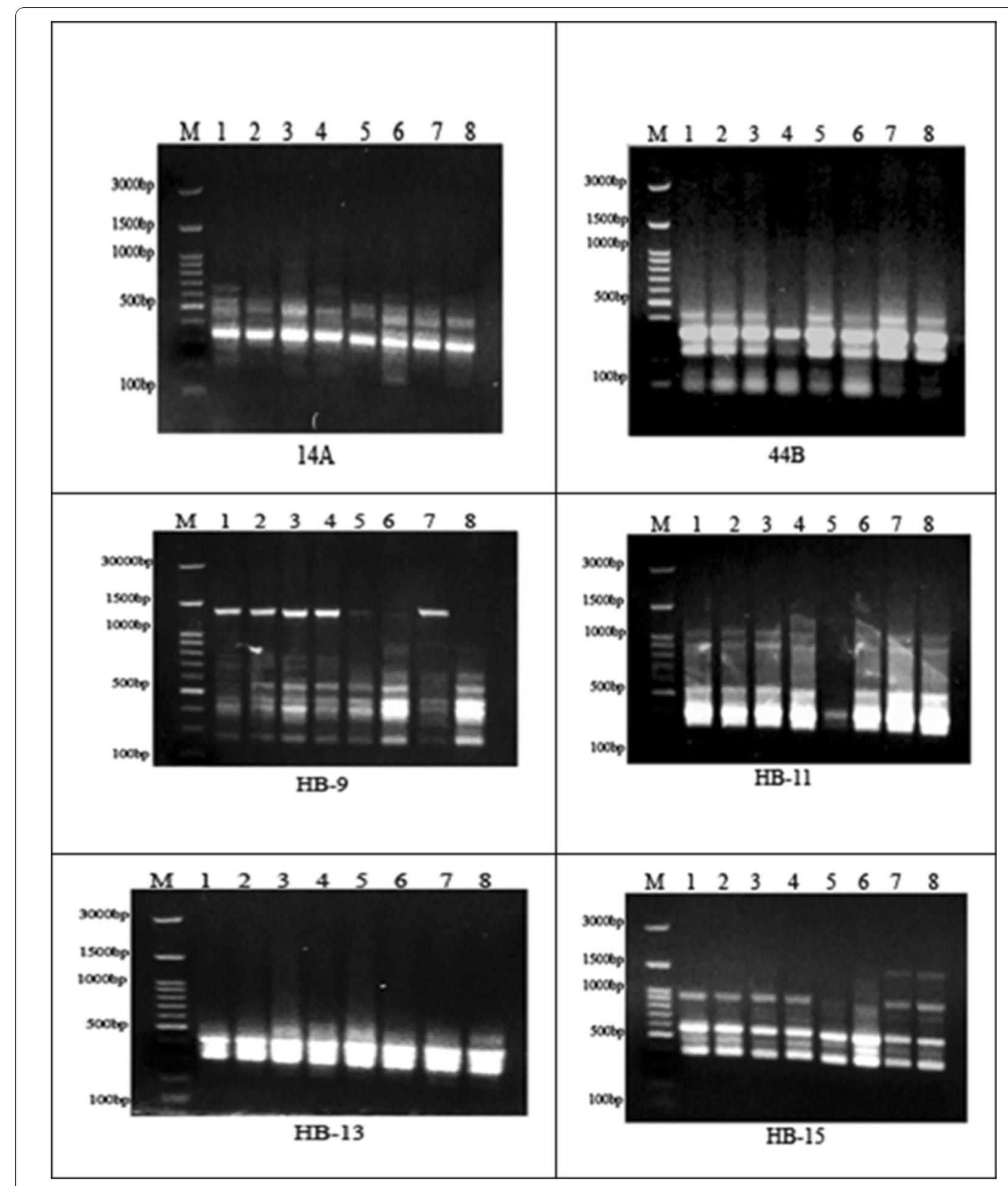

Fig. 4 ISSR amplification profile of potato mutants and four potato parent cultivars produced by 6 different primers as affected by gamma rays. M, marker, lanes 1, 3, 5 and 7 untreated Lady Rosetta, Diamante, Gold and Santana; lanes 2, 4, 6 and 8 gamma-treated ones 
Table 6 Variation among treated and control plants of potato cultivars in the number of bands of six ISSR primers

\begin{tabular}{|c|c|c|c|c|c|c|c|c|c|c|}
\hline \multirow[t]{3}{*}{ Primer name } & \multirow[t]{3}{*}{ Band no. } & \multirow[t]{3}{*}{ MW bp } & \multicolumn{8}{|c|}{ Cultivars } \\
\hline & & & \multicolumn{2}{|c|}{ Lady Rosetta } & \multicolumn{2}{|c|}{ Diamante } & \multicolumn{2}{|l|}{ Gold } & \multicolumn{2}{|c|}{ Santana } \\
\hline & & & Con & Tre & Con & Tre & Con & Tre & Con & Tre \\
\hline \multirow[t]{6}{*}{$14 \mathrm{~A}$} & 1 & 680 & 1 & 0 & 0 & 1 & 0 & 1 & 0 & 1 \\
\hline & 2 & 570 & 1 & 1 & 0 & 0 & 1 & 1 & 1 & 0 \\
\hline & 3 & 490 & 1 & 1 & 1 & 1 & 1 & 1 & 1 & 1 \\
\hline & 4 & 365 & 1 & 1 & 1 & 1 & 1 & 1 & 1 & 1 \\
\hline & 5 & 230 & 1 & 1 & 1 & 1 & 0 & 1 & 0 & 1 \\
\hline & Total & & 5 & 4 & 3 & 4 & 3 & 5 & 3 & 4 \\
\hline \multirow[t]{6}{*}{$44 B$} & 1 & 415 & 1 & 1 & 1 & 0 & 1 & 1 & 1 & 1 \\
\hline & 2 & 340 & 1 & 1 & 1 & 1 & 1 & 1 & 1 & 1 \\
\hline & 3 & 260 & 1 & 1 & 1 & 1 & 1 & 1 & 1 & 1 \\
\hline & 4 & 175 & 1 & 1 & 1 & 1 & 1 & 1 & 1 & 1 \\
\hline & 5 & 100 & 1 & 1 & 1 & 1 & 1 & 1 & 1 & 1 \\
\hline & Total & & 5 & 5 & 5 & 4 & 5 & 5 & 5 & 5 \\
\hline \multirow[t]{8}{*}{ HB 9} & 1 & 1360 & 1 & 1 & 1 & 1 & 1 & 1 & 1 & 1 \\
\hline & 2 & 800 & 1 & 1 & 1 & 1 & 0 & 0 & 0 & 0 \\
\hline & 3 & 690 & 1 & 1 & 1 & 1 & 1 & 1 & 1 & 1 \\
\hline & 4 & 570 & 1 & 1 & 1 & 1 & 1 & 1 & 0 & 1 \\
\hline & 5 & 465 & 1 & 1 & 1 & 1 & 1 & 1 & 1 & 1 \\
\hline & 6 & 415 & 1 & 1 & 1 & 1 & 1 & 1 & 1 & 1 \\
\hline & 7 & 185 & 1 & 1 & 1 & 1 & 1 & 1 & 1 & 1 \\
\hline & Total & & 7 & 7 & 7 & 7 & 6 & 6 & 5 & 6 \\
\hline \multirow[t]{6}{*}{ HB 11} & 1 & 1080 & 1 & 1 & 1 & 1 & 0 & 1 & 1 & 1 \\
\hline & 2 & 910 & 1 & 1 & 1 & 1 & 1 & 1 & 1 & 1 \\
\hline & 3 & 530 & 1 & 1 & 1 & 1 & 1 & 1 & 1 & 1 \\
\hline & 4 & 410 & 1 & 1 & 1 & 1 & 1 & 1 & 1 & 1 \\
\hline & 5 & 340 & 1 & 1 & 1 & 1 & 1 & 1 & 1 & 1 \\
\hline & Total & & 5 & 5 & 5 & 5 & 4 & 5 & 5 & 5 \\
\hline \multirow[t]{5}{*}{$\mathrm{HB} 13$} & 1 & 480 & 1 & 0 & 1 & 1 & 1 & 0 & 1 & 1 \\
\hline & 2 & 425 & 1 & 1 & 1 & 1 & 1 & 1 & 1 & 1 \\
\hline & 3 & 315 & 1 & 1 & 1 & 1 & 1 & 1 & 1 & 1 \\
\hline & 4 & 265 & 1 & 1 & 1 & 1 & 1 & 1 & 1 & 1 \\
\hline & Total & & 4 & 3 & 4 & 4 & 4 & 3 & 4 & 4 \\
\hline \multirow[t]{10}{*}{ HB 15} & 1 & 1430 & 0 & 0 & 0 & 0 & 0 & 0 & 1 & 1 \\
\hline & 2 & 965 & 1 & 1 & 1 & 1 & 1 & 0 & 1 & 1 \\
\hline & 3 & 820 & 0 & 0 & 0 & 0 & 0 & 1 & 0 & 0 \\
\hline & 4 & 715 & 1 & 1 & 1 & 1 & 0 & 0 & 0 & 0 \\
\hline & 5 & 630 & 1 & 1 & 1 & 1 & 1 & 1 & 1 & 1 \\
\hline & 6 & 600 & 1 & 1 & 1 & 1 & 1 & 1 & 1 & 1 \\
\hline & 7 & 490 & 1 & 1 & 1 & 1 & 1 & 1 & 1 & 1 \\
\hline & 8 & 430 & 1 & 1 & 1 & 1 & 1 & 1 & 1 & 1 \\
\hline & Total & & 6 & 6 & 6 & 6 & 5 & 5 & 6 & 6 \\
\hline & Overall bands & & 32 & 30 & 30 & 30 & 27 & 29 & 28 & 30 \\
\hline
\end{tabular}

context, salt-tolerant cultivars of various crops, such as rice showed high activity of POD, which quenched reactive oxygen species (ROS) and indirectly increased plant fresh weight [25]. Our results confirm the previous findings of [33] who found that wild potato (S. bulbocastanum) had high activity of antioxidant enzymes (POD, $\mathrm{SOD}$ and CAT) under saline conditions in vitro. However, the reduction of salt tolerance capacity was correlated 


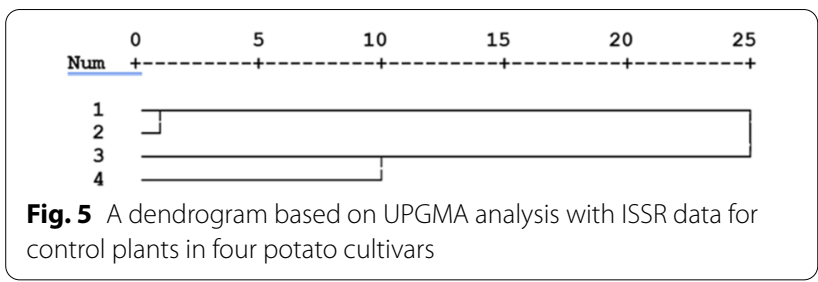

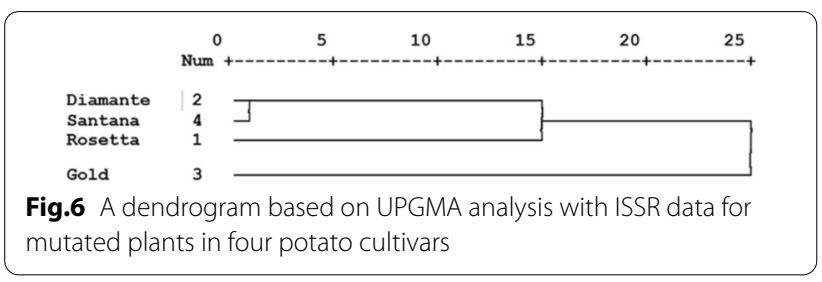

with the absence of some isoenzymes like PODs and PPOs in salt-sensitive Gold potato after gamma rays application, as shown in Figs. 2 and 3 and Tables 3 and 4. Furthermore, POD and PPO isoenzymes bands were denser (high activity indicator) in salt-tolerant Santana potato than other cultivars. As known, isoperoxidase catalyzes the breakdown of $\mathrm{H}_{2} \mathrm{O}_{2}$ to $\mathrm{H}_{2} \mathrm{O}$ and $\mathrm{O}_{2}$ in the presence of ascorbic acid in taro (Colocasia esculenta) under salinity conditions [34]. In addition, PODs are ubiquitous enzymes in the plant, and often occur as multiple isoforms. For instance, they are encoded with 73 different genes in Arabidopsis thaliana [35]. Such abundance of isoforms is consistent with diverse physiological functions in peroxidases family [36]. Results of the current study were in consistence with previous findings that confirm the role of gamma rays improving salt-stressed and non-stressed potato growth [37, 38].

The presence or absence of isoenzymes is mainly related to changes in potato genetic structure. Therefore, genetic marker analysis using ISSR with six different primers was used. According to primer sequence and potato genotype, obvious unique negative and positive bands with different base pairs in mutant plantlets could easily be detected in comparison to the control (Fig. 4 and Table 6). Mutation can induce changes in genome sequence, which affect primer-annealing sites, reduce the number of binding sites for Taq polymerase, and change DNA bands in ISSR profile. One-base difference in genome sequence may hinder the annealing of the primers [39].

The range of amplified sizes by each primer across different mutated and control plants was noteworthy (100 and $1430 \mathrm{bp}$ using 44B and HB15 primers, respectively). The $14 \mathrm{~A}$ primer was an efficient genetic marker between mutated and unmutated potato genotypes (Table 5), because it has more CTC codon sequence (Table 1), which might be an indicator of DNA of potato genotypes that had more GAG codon sequence. In the same context, HB11 primer that had more TGT nucleotides repeats was the lowest effective primer, which means that the genome of all four potato cultivars had low ACA repeats. This difference was detected by loci test. In case of the wide divergent sizes, the actual number of nucleotides in the allele would need to be proven by sequencing. However, the allele size is not only dependent on the number of nucleotides, but also there are several factors affecting the allele size including the mobility of the fragment by electrophoresis, the distance of the allele from the standard used, the type of fluorescent label used, and the use of different instruments with different softwares [40]. Moreover, Table 5 reveals that out of 34 bands scored, there were 22 monomorphic-identical bands for all mutated and control plants. This may indicate that the primer has annealing sites at the same position of all genotypes' genomes and/or may be attributed to the amplification of highly conserved regions in the genome that make amplification bands similar to each other in molecular weight (monomorphic) [41].

The increment of genetic distance between the most salt-sensitive Gold cv. and other genotypes has proven that mutation took place because of gamma rays (Fig. 6). Also, the presence or absence of bands was clearer in Gold cv. than other cultivars. Therefore, bands with 1080 and $820 \mathrm{bp}$ were, respectively, existed in gammatreated Gold cv. using HB11 and HB15, but bands with 480 and 965 bp were not detected using HB13 and HB15, respectively. On the other hand, salt-tolerant Santana cv. showed the presence of both genetic bands with 230 and 570 bp using 14A and HB9 primers, respectively. Gaining bands may be due to the insertion and loss of bands related to nucleotides deletion. These results may confirm that induced mutagenesis using gamma rays could be conducted in wide aspect, but individual plant reacted different to the induced mutant [42]. In addition, new bands found in the mutated plants of four potato cultivars could be referred to ISSR primers, which have possible linkage changes in non-coding regions that led to specific changes in the genome after gamma-ray treatment [43].

Because the ISSR primers were amplified with numerous sequences, bands were extremely precise to classify the genotype. Therefore, Santana cv. had a unique fingerprint in the 1430-pb site, which can be a selected marker for this cultivar. The negative unique bands could be applied in further investigations, as practical markers to recognize tolerant and sensitive genotypes of the potato cultivars [44].The high values of genetic similarity (93 and $87 \%$ for unmuted and muted plantlets, respectively) between Rosetta and Diamond potatoes (Fig. 5) could 
be used as an indication that a large part of the genome of both cultivars is identical. This is primarily due to the lack of parental diversity, because both cultivars may share similar parents in the pedigree [13]. This explanation is might be due to the lack of ISSR primers selection, which makes it difficult to generalize them in control and mutated plants [16].

\section{Conclusion}

We conclude that mutation of potato plants induced by gamma radiation application induces salt resistance in the plant, especially in cv Santana. The applied radiations induced new genetic bands that can be expressed as new isoenzymes such as peroxidase or polyphenol oxidase, responsible for quenching reactive oxygen species under salt stress.

\section{Acknowledgements}

Not applicable.

\section{Authors' contributions}

The authors confirm that they have equal contribution. All authors read and confirm the final manuscript.

\section{Funding}

Not applicable.

\section{Availability of data and materials}

Not applicable.

\section{Declarations}

Ethics approval and consent to participate

Not applicable.

\section{Consent for publication}

Not applicable.

\section{Competing interests}

The authors declare that they have no competing interests.

\section{Author details \\ ${ }^{1}$ Department of Agricultural Botany, Faculty of Agriculture, Suez Canal University, Ismailia, Egypt. ${ }^{2}$ Department of Plant Physiology, Institute of Biol- ogy, Faculty of Agriculture and Biology, Warsaw University of Life Sciences, 02-776 Warsaw, Poland. ${ }^{3}$ Department of Bioengineering, West Pomeranian University of Technology in Szczecin, 17 Słowackiego Street, 71-434 Szczecin, Poland. ${ }^{4}$ Agriculture Botany Department, Faculty of Agriculture, Tanta Univer- sity, Tanta, Egypt.}

Received: 3 April 2021 Accepted: 21 May 2021

Published online: 14 July 2021

\section{References}

1. Alisdair R, Fernie R, Willmitzer L. Molecular and biochemical triggers of potato tuber development. Plant Physiol. 2001;127:1459-65.

2. Katerji N, van Hoorn JW, Hamdy A, et al. Salt tolerance classification of crops according to soil salinity and to water stress day index. Agri Water Manag. 2000:43:99-109.

3. Helaly MN, El-Hosieny H, Elsheery N, Kalaji HM. Effect of biofertilizers and putrescine amine on the physiological features and productivity of date palm (Phoenix dactylifera L.) grown on reclaimed-salinized soil. Trees. 2016;30:1149-61.
4. Elsheery NI, Helaly MN, Omar SA, John SV, Zabochnicka-Swiątek M, Kalaji HM, Rastogi A. Physiological and molecular mechanisms of salinity tolerance in grafted cucumber. South Afr J Botany. 2020;130:90-102.

5. Elsheery N, Helaly M, Elshoiseiny H, AlamEldin S. Zinc oxide and silicone nanoparticles to improve the resistance mechanism and annual productivity of salt-stressed mango trees. Agron. 2020;10:558.

6. Kawasaki S, Borchert C, Deyholos M, et al. Gene expression profiles during the initial phase of salt stress in rice. Plant Cell. 2001;13:889-905.

7. Zhu JK. Salt and drought stress signal transduction in plants. Annu Rev Plant Biol. 2002;53:247-73.

8. Howard HW. The production of new varieties. In: Harris PM, editor. The Potato Crop: The scientific Basis for improvement. London: Chapman and Hall; 1978. p. 607-46.

9. Beyaz R, Kahramanogullari CT, Yildiz C, Darcin ES, Yildiz M. The effect of gamma radiation on seed germination and seedling growth of Lathyrus chrysanthus Boiss. under in vitro conditions. J Environ Radioact. 2016;162-163:129-33.

10. Beyaz R, Sancak C, Yildiz Ç, Kuşvuran Ş, Yildiz M. Physiological responses of the M1 sainfoin (Onobrychis viciifolia Scop) plants to gamma radiation. Appl Radiat Isotop. 2016;118:73-9.

11. Beyaz R, Yildiz M. The use of gamma irradiation in plant mutation breeding. Plant Eng. 2017;1:33-46.

12. Beyaz R. Impact of gamma irradiation pretreatment on the growth of common vetch (Vicia Sativa L.) seedlings grown under salt and drought stress. Int J Radiat Biol. 2020;2:257-66

13. Penna $S$, Vitthal SB, Yadav PV. In vitro mutagenesis and selection in plant tissue cultures and their prospects for crop improvement. Bioremed Biodivers Bioavail. 2012;6:6-14.

14. Afrasiab $\mathrm{H}$, Iqbal J. In vitro techniques and mutagenesis for the genetic improvement of potato cvs. desiree and diamant. Pak J Bot. 2010;42:1629-37.

15. Cheng $L$, Yang $H$, Lin $B$, et al. Effect of gamma-ray radiation on physiological, morphological characters and chromosome aberrations of minitubers in Solanum tuberosum. Int J Radiat Biol. 2010;86:791-9.

16. Yaycili O, Alikamanoğlu S. Induction of salt-tolerant potato (Solanum tuberosum L.) mutants with gamma irradiation and characterization of genetic variations via RAPD-PCR analysis. Turk J Biol. 2012;36:405-12.

17. AL-Daoude A, Alsafadi B, Al-Nabulsi I, et al. Studying the possibility of isolating and characterizing genes responsible for salinity tolerance in some gamma irradiation-induced potato mutants. Report on Laboratory Reconnaissance Experiment Department of Molecular Biology and Biotechnology. Syrian Arab Rep. Atomic Energy Commission, 2008.

18. Roy A, Bandyopadhyay A, Mahapatra AK, et al. Evaluation of genetic diversity in jute (Corchorus species) using STMS. ISSR and RAPD markers PI Breed. 2006;125:292-7.

19. AL-Hussaini Z, Yousif S, AL-Ajeel S. Utilization of Differential Display Reverse Trancrptase-DDRT for detection of salt tolerant clones of Potato Solanuim tuberosum L. Biosci Res 2019; 16: 1891-1899.

20. Sharabash MT. Radiation induced variation in potato for tolerance to salinity using tissue culture technique. In Vitro Techniques for Selection of Radiation Induced Mutations Adapted to Adverse Environmental Conditions 2001 IAEA Vienna, IAEA-TECDOC-1227 ISSN 1011-4289.

21. Murashige T, Skoog T. A revised medium for rapid growth and bioassays with tobacco tissue cultures. Physiol Plant. 1962;15:473-9.

22. Steel RGD, Torrie JH, Dickey DA. Principles and Procedures of Statistics: a biometrical approach. New York: McGraw-Hill; 1997.

23. Mukherjee SP, Choudhuri MA. Implication of water stress-induced changes in the level of endogenous ascorbic acid and hydrogen peroxide in Vigna seedlings. Physiol Plant. 1983;58:166-70.

24. Bergmeyer HU. Methods of Enzymatic Analysis 1. New York: Academic press; 1974.

25. Kar M, Mishra D. Catalase, peroxidase and polyphenol oxidase activities during rice leaf senescence. Plant physiol. 1976;57:315.

26. Stagemann $\mathrm{H}$, Burgermeister W, Frankcksen $\mathrm{H}$, et al. Manual of gel electrophoresis and isoelectric focusing with the apparatus PANTAPHOR. 1985. Inst. Biochem. Messeweg 11, D- 3300. Braunschweig, West Germany.

27. Brown AHD. Isozymes, plant population genetic structure and genetic conservation. Theor Appl Genet. 1978;52:145-57.

28. Sambrook J, Russell DW. Molecular Cloning. A Laboratory Manual. Cold Spring Harbor: Cold Spring Harbor Laboratory Press; 2001. 
29. Williams JGK, Kubelk AR, Livak KJ, et al. DNA polymorphisms amplified by arbitrary primers are useful as genetic markers. Nucl Acid Res. 1990;18:6231-5

30. Yang X, Quiros CF. Identification and classification of celery cultivars with RAPD markers. Theor Appl Genet. 1993;86:205-12.

31. Blair RJR, Morris JS, Frith CD, Perrett DI, Dolan RJ. Dissociable neural responses to facial expressions of sadness and anger. Brain. 1999;122:883-93.

32. M-STAT. A Microcomputer program for the design management and analysis of agronomic research experiments. Michigan State Univ. 1990.

33. Daneshmand F, Arvin MJ, Kalantari KM. Effect of acetylsalicylic acid (Aspirin) on salt and osmotic stress tolerance in Solanum bulbocastanum in Vitro: enzymatic antioxidants. Am-Euras J Agric Environ Sci. 2009;6:92-9.

34. Chang $H$, Siegel BZ, Siegel SM. Salinity induced changes in isoperoxidase in taro Colocasia esculenta. Phytochem. 1984;23:233-5.

35. Duroux L, Welinder KG. The peroxidase gene family in plants: A phylogenetic overview. J Mol Evol. 2003;57:397-407.

36. Siegel BZ. Plant peroxidases-an organismic perspective. PI Growth Reg. 1993;12:303-12

37. Ahmed OI. Biochemical changes of potatoes during growth and storage as affected by gamma radiation. Ph.D. Thesis, Fac. Agric., Cairo Univ., Egypt, 2004; p. 223.

38. Al-Safadi B, Arabi M. In vitro induction, isolation, and selection of potato mutants tolerant to salinity. Adv Hort Sci. 2007;21:127-32.
39. Atak C, Celik O, Acik L. Genetic analysis of Rhododendron mutants using random amplified polymorphic DNA (RAPD). Pak J Bot. 2011;43:1173-82.

40. Stewart S, Wickramasinghe D, Dorrance A, et al. Comparison of three microsatellite analysis methods for detecting genetic diversity in Phytophthora sojae Stramenopila: Oomycete). Biotech Lett. 2011;33:2217-23.

41. Ramiz TA, Mehraj A, Alamdar CM. Genetic identification of diploid and tetraploid wheat Species with RAPD markers. Turk J Biol. 2007:31:173-80.

42. Yulita K, Ridwan A. Molecular characterization of induced mutation of jewawut (Setaria italica ssp. italica) from Buru Island Indonesia using SRAP. Biodiversity. 2018;19:1160-8.

43. Žiarovská J, Ražná K, Labajová M. Using of Inter Microsatellite Polymorphism to evaluate gamma-irradiated Amaranth mutants. Emir J Food Agric. 2013;25:673-81.

44. Huseynova M, Rustamova SM, Nasrullayeva MY, et al. Screening of barley genotypes for drought tolerance using molecular markers. Int J Plant Sci Ecol. 2015;1:88-92.

\section{Publisher's Note}

Springer Nature remains neutral with regard to jurisdictional claims in published maps and institutional affiliations.

\section{Submit your manuscript to a SpringerOpen ${ }^{\odot}$ journal and benefit from:}

- Convenient online submission

- Rigorous peer review

- Open access: articles freely available online

- High visibility within the field

- Retaining the copyright to your article

Submit your next manuscript at $\boldsymbol{\nabla}$ springeropen.com 